\title{
Brachylaena elliptica and B. ilicifolia (Asteraceae): A Comparative Analysis of their Ethnomedicinal Uses, Phytochemistry and Biological Activities
}

\author{
Alfred Maroyi
}

Department of Botany, University of Fort Hare, Private Bag X1314, Alice 5700, South Africa

\begin{abstract}
Brachylaena elliptica and B. ilicifolia are shrubs or small trees widely used as traditional medicines in southern Africa. There is need to evaluate the existence of any correlation between the medicinal uses, phytochemistry and pharmacological properties of the two species. Therefore, in this review, analyses of the ethnomedicinal uses, phytochemistry and biological activities of $B$. elliptica and $B$. ilicifolia are presented. Results of the current study are based on data derived from several online databases such as Scopus, Google Scholar, PubMed and Science Direct, and pre-electronic sources such as scientific publications, books, dissertations, book chapters and journal articles. The articles published between 1941 and 2020 were used in this study. The leaves and roots of $B$. elliptica and $B$. ilicifolia are mainly used as a mouthwash and ethnoveterinary medicines, and traditional medicines for backache, hysteria, ulcers of the mouth, diabetes, gastro-intestinal and respiratory problems. This study showed that sesquiterpene lactones, alkaloids, essential oils, flavonoids, flavonols, phenols, proanthocyanidins, saponins and tannins have been identified from aerial parts and leaves of $B$. elliptica and $B$. ilicifolia. The leaf extracts and compounds isolated from the species exhibited antibacterial, antidiabetic, antioxidant and cytotoxicity activities. There is a need for extensive phytochemical, pharmacological and toxicological studies of crude extracts and compounds isolated from $B$. elliptica and $B$. ilicifolia.
\end{abstract}

Keywords: Asteraceae, Brachylaena elliptica, Brachylaena ilicifolia, indigenous pharmacopeia, traditional medicine.

\section{INTRODUCTION}

The genus Brachylaena $\mathrm{R}$. Br. is one of the most important sources of traditional medicines among the Asteraceae genera. The family Asteraceae is characterized by phytochemical compounds such as polyacetylenes, acetophenones, chalcone, caffeoylquinic acids, diterpenoids, phloroglucinols, polyacetylenes, flavonoids, pyrrolizidine alkaloids and polyphenols [1-5]. Biological activities associated with Asteraceae species include analgesic, anthelmintic, anti-allergic, antidiabetic, antimigraine, antiinflammatory, antiproliferative, antimicrobial, cardiotonic, antioxidant, neuroprotective, antipyretic, antiulcer, antinociceptive, antimalarial, antiprotozoal, antileishmanial, cytotoxicity and hepatoprotective properties [2,3,5-9]. Brachylaena elliptica (Thunb.) DC. and B. ilicifolia (Lam.) E. Phillips and Scheweick. are widely used as herbal medicines in southern Africa [10]. The roots of $B$. elliptica are an ingredient of "inembe" herbal concoction, mixed with the roots of Cyphostemma natalitium (Szyszyl.) J.J.M. van der Merwe, Gunnera perpensa L., Rhoicissus tridentata subsp. cuneifolia (Eckl. \& Zeyh.) Urton and Triumfetta rhomboidea Jacq. [10,11]. The "inembe" herbal concoction is used to induce or augment labour,

*Address correspondence to this author at the Department of Botany, University of Fort Hare, Private Bag X1314, Alice 5700, South Africa:

Tel/Fax: 0027719600326; E-mail: amaroyi@ufh.ac.za postnatal medication to expel afterbirth, abortifacient, and also administered to animals to expel placenta and to treat and manage endometritis [10,12-15]. The leaves of $B$. elliptica and $B$. ilicifolia are traded as traditional medicines in the informal herbal medicine markets in the Eastern Cape province in South Africa [16-18]. Apart from being used as herbal medicines for similar medical conditions, B. elliptica and B. ilicifolia have been recorded in overlapping geographical areas in southern Africa (Figure 1). It is, therefore, within this context that the current review was undertaken aimed at providing a comparative analysis of the ethnomedicinal uses, phytochemistry and biological activities of $B$. elliptica and $B$. ilicifolia.

\section{Botanical Description of Brachylaena elliptica and B. ilicifolia}

Brachylaena elliptica is a shrub or a small tree growing up to 7 metres in height [19]. The bark of $B$. elliptica is light grey to brown in colour, vertically fissured with young branches that are grooved with very fine hairs. The leaves are lanceolate to ovate in shape, dark green above and white-felted below. The leaf margins are entire to irregularly toothed with a broadly tapering to rounded apex. The flower head is terminal and axillary branched cluster that is creamy white in colour with male florets in small heads while female florets are in large heads. The fruit is a small nutlet with an apical tuft of bristles. Brachylaena elliptica has been recorded in coastal areas, river bush,

() 2020 SET Publisher 


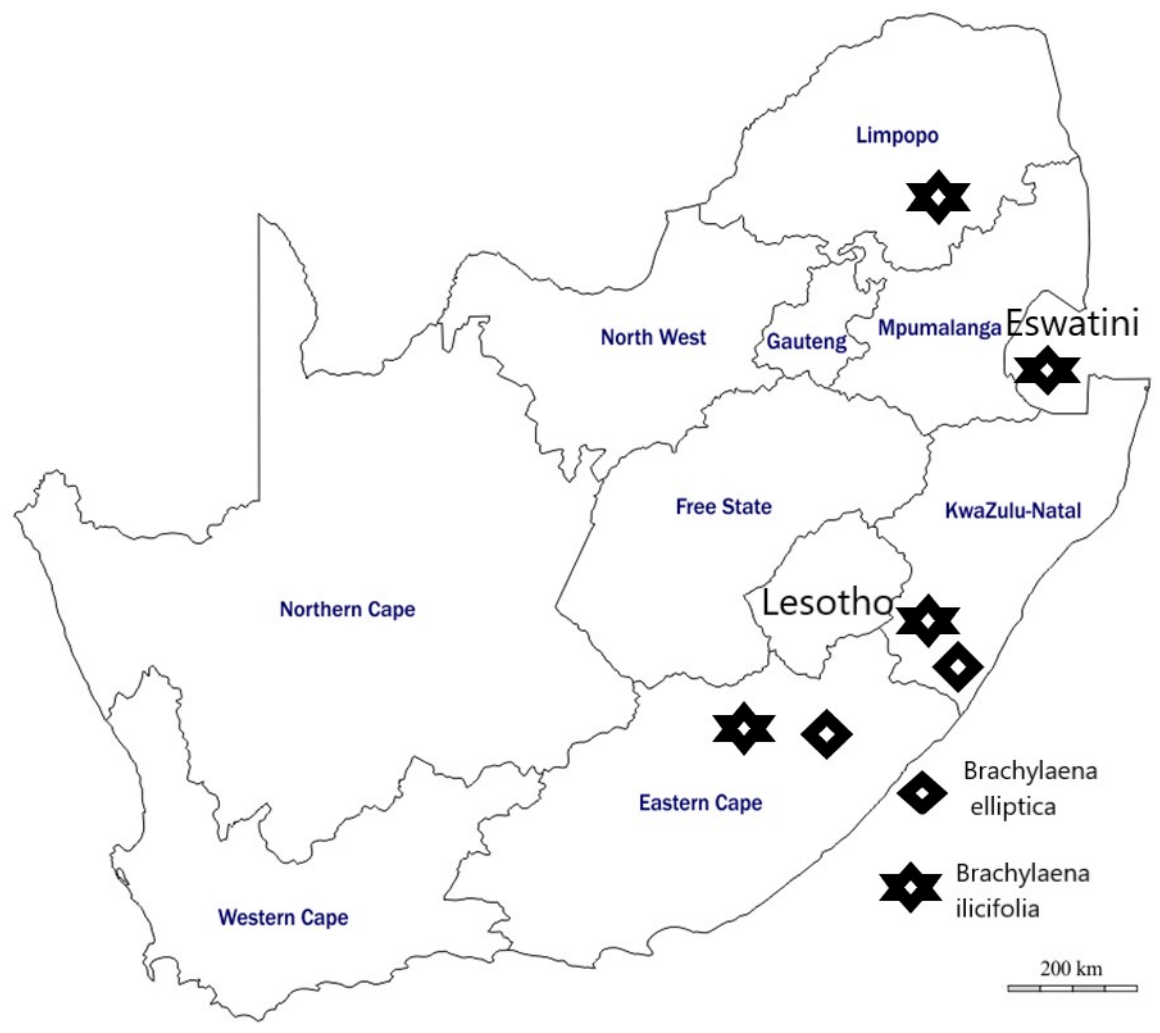

Figure 1: Geographical distribution of Brachylaena elliptica and B. ilicifolia.

valley bushveld, scrub, grassland, on rocky outcrops and along evergreen forest margins at sea level to $1200 \mathrm{~m}$ above sea level [19,20,21]. Brachylaena ilicifolia is an evergreen shrub or a small tree growing up to 5 metres in height $[19,22]$. The main stem is multi-stemmed with dark grey-brown bark that is rough and fissured in older trees. The leaves are crowded at the ends of the branches, alternate, elliptic to ovate in shape, shiny green and smooth above and below are usually covered with white hairs and prominent midrib. The leaf base is rounded to broadly tapering, with entire to finely toothed leaf margins. The flower heads of $B$. ilicifolia are grouped into axillary panicles with creamy-white coloured flowers characterized by a faint, sweet scent. The fruits of $B$. ilicifolia are small achenes characterized by an apical tuft of creamy brown bristles $[21,23]$. Brachylaena ilicifolia has been recorded in bush, scrub forest, on rocky hillsides in seasonally dry open woodland and in dry thickets along watercourses at an altitude ranging from $20 \mathrm{~m}$ to $1350 \mathrm{~m}$ above sea level $[19,20]$.

\section{Medicinal Uses of Brachylaena elliptica and $B$. ilicifolia}

The leaves and roots of both $B$. elliptica and $B$. ilicifolia are widely used as traditional medicines in southern Africa. A total of 15 human and livestock diseases and ailments are treated with herbal concoctions prepared from $B$. elliptica and $B$. ilicifolia (Table 1). The leaves and roots of $B$. elliptica and $B$. ilicifolia are mainly used as a mouthwash and ethnoveterinary medicines, and traditional medicines for backache, hysteria, ulcers of the mouth, diabetes, gastro-intestinal and respiratory problems (Table 1, Figure 2). In South Africa, the roots of $B$. elliptica are used as substitutes for those of Gymnanthemum corymbosum (Thunb.) H. Rob. as an abortifacient and ethnoveterinary medicine, and a traditional medicine for stomach ache and hysteria [10,24-29]. In South Africa, the leaves of $B$. ilicifolia are mixed with those of Leucas capensis (Benth.) Engl. and sap of Aloe ferox Mill. and used as ethnoveterinary medicine $[28,30,31]$.

\section{Phytochemical and Biological Activities of Brachylaena elliptica and B. ilicifolia}

Zdero and Bohlmann [50] identified sesquiterpene lactones, elemanolide and onopordopicrin from the aerial parts of $B$. elliptica. Sagbo [51] and Sagbo et al. [52] identified alkaloids, flavonoids, flavonols, phenols, proanthocyanidins, saponins and tannins from leaves of both B. elliptica and B. ilicifolia. Furthermore, Sagbo [51] identified essential oils from the leaves of both $B$. elliptica and $B$. ilicifolia with benzoic acid, 2,5bis(trimethylsiloxy)- ,trimethylsilyl ester, butylated hydroxytoluene, caryophyllene oxide and oxalic acid,cyclohexylmethyltridecyl ester reported in both 
Table 1: Medicinal Applications of Brachylaena elliptica and B. ilicifolia

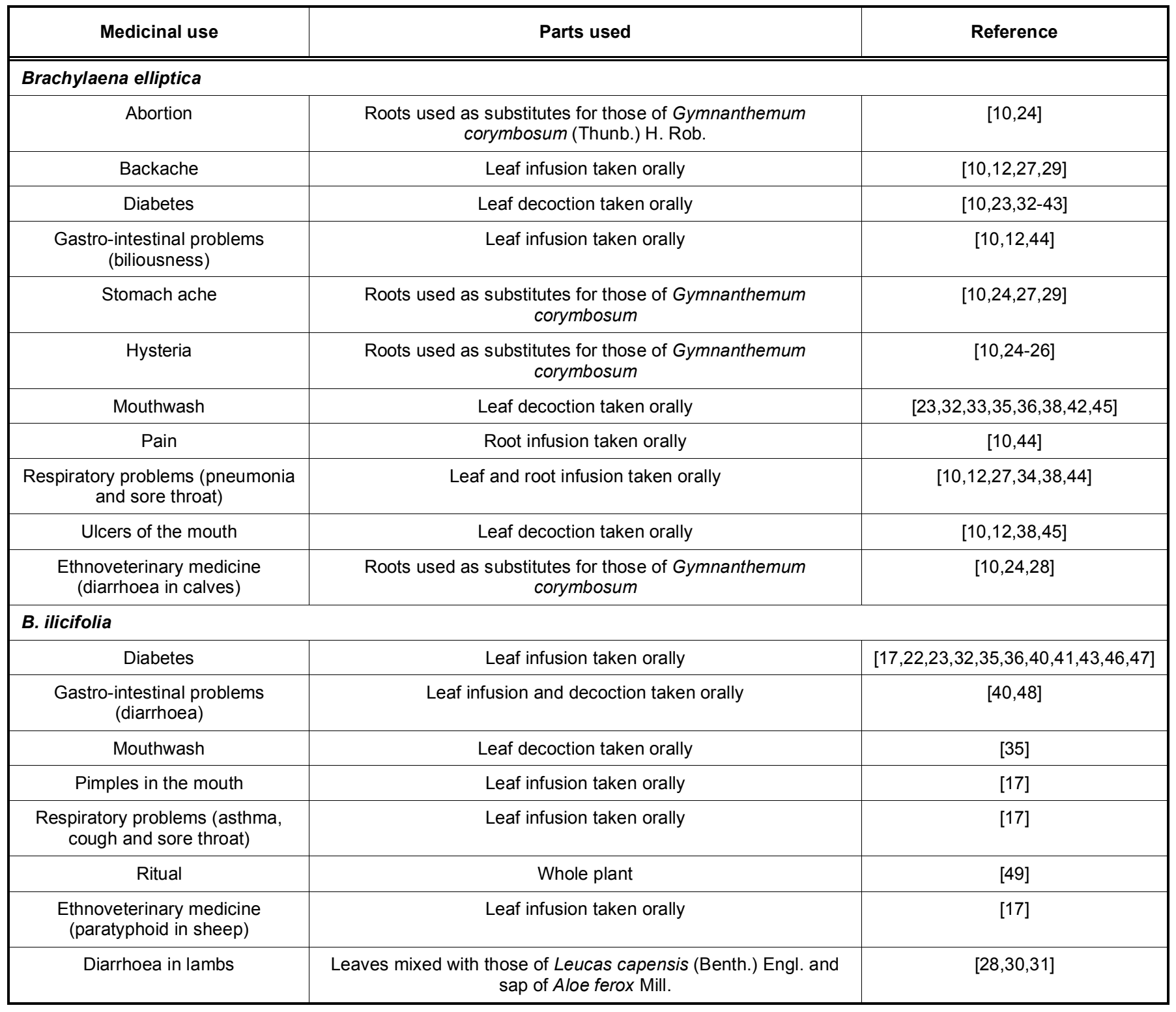

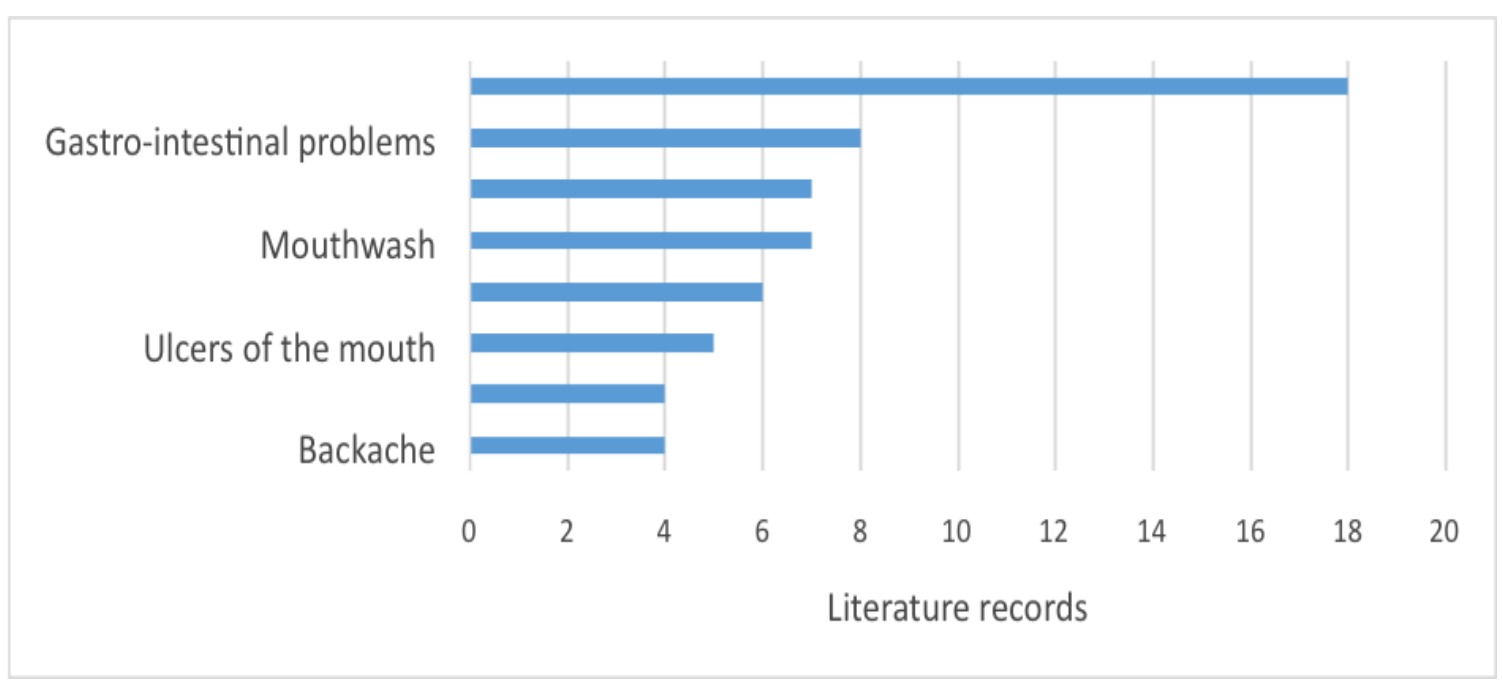

Figure 2: Medicinal applications of Brachylaena elliptica and B. ilicifolia derived from literature records. 
Table 2: Phytochemical Composition of Brachylaena elliptica and B. ilicifolia

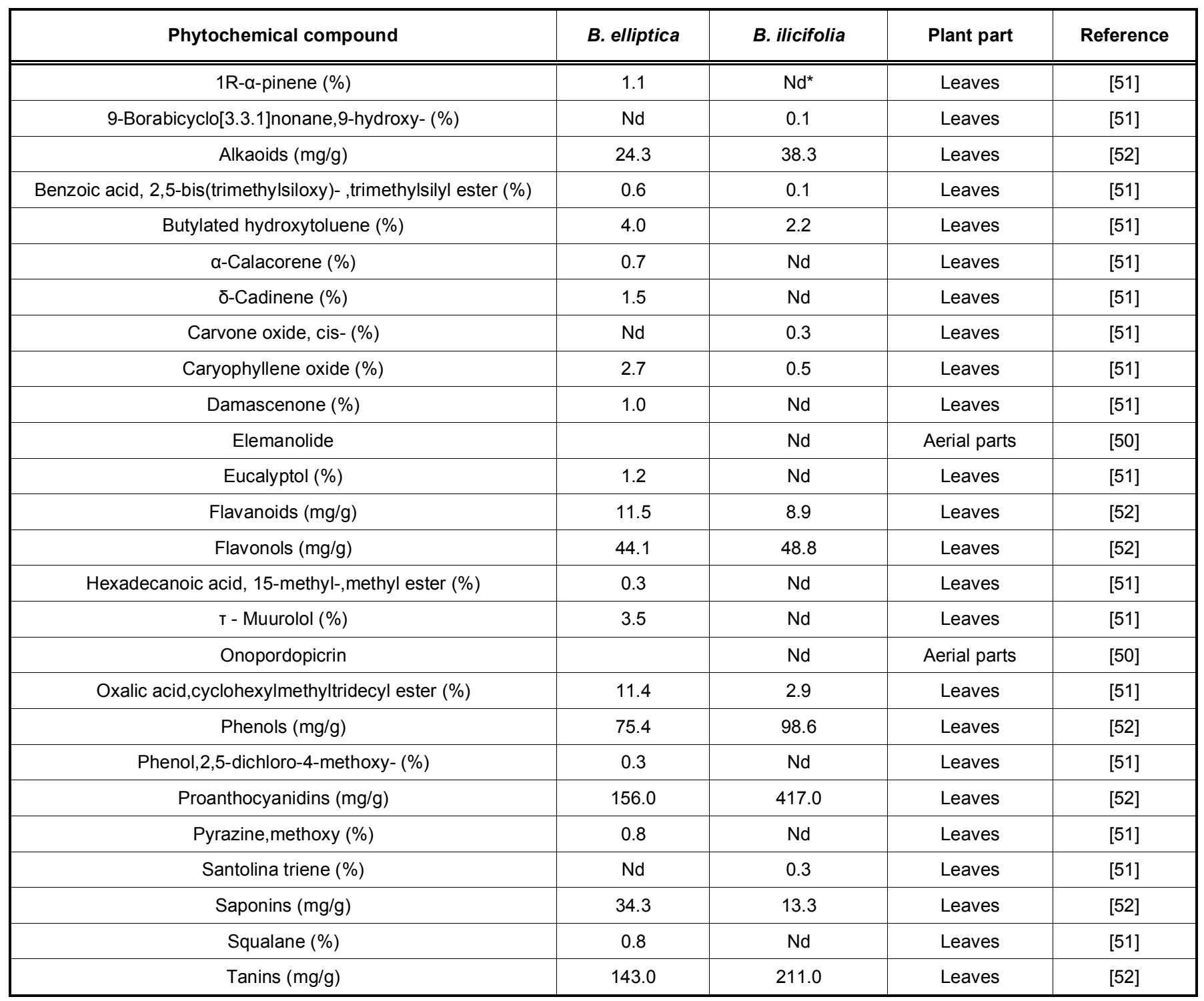

${ }^{*} \mathrm{Nd}=$ not detected.

species (Table 2). Some of these phytochemical compounds may be responsible for the biological activities of the species.

Sagbo et al. [52] evaluated the antibacterial activities of ethanol extracts of $B$. elliptica leaves against Pseudomonas aeruginosa, Proteus mirabilis, Proteus vulgaris, Staphylococcus aureus and Streptococcus pyogenes using the agar dilution method with amoxycillin and ciprofloxacin as positive controls. The extract exhibited activities against all tested pathogens with the exception of Staphylococcus aureus with the minimum inhibitory concentration (MIC) values ranging from $2.5 \mathrm{mg} / \mathrm{mL}$ to $5.0 \mathrm{mg} / \mathrm{mL}$ in comparison to the MIC values of $0.3 \mathrm{mg} / \mathrm{mL}$ to 0.6 $\mathrm{mg} / \mathrm{mL}$ exhibited by the positive controls [52]. Sagbo et al. [52] evaluated the antibacterial activities of ethanol extracts of $B$. ilicifolia leaves against Pseudomonas aeruginosa, Proteus mirabilis, Proteus vulgaris, Staphylococcus aureus and Streptococcus pyogenes using the agar dilution method with amoxycillin and ciprofloxacin as positive controls. The extract exhibited activities against all tested pathogens with the exception of Proteus vulgaris with the MIC values ranging from $2.5 \mathrm{mg} / \mathrm{mL}$ to $5.0 \mathrm{mg} / \mathrm{mL}$ [52].

Preliminary antidiabetic evaluations carried out by Marles and Farnsworth [53] showed that extracts from the roots and stems of $B$. elliptica lowered blood glucose in experimental animals. Similarly, Sagbo et al. [42] evaluated the antidiabetic activities of aqueous leaf extract of $B$. elliptica by assessing the effects of the extract on glucose utilization in HepG2 cells and L6 myoblasts, lipid accumulation in 3T3-L1, glucose 
metabolism in INS-1 cells and nitric oxide (NO) production in RAW macrophage cells. The authors also assessed the effects of the extract on alpha-amylase, alpha-glucosidase, pancreatic lipase, dipeptidyl peptidase IV (DPP-IV), collagenase and cytochrome P450 (3A4) enzymes. The extract exhibited activities by causing an increase in the glucose uptake in HepG2 liver cells, producing a concentration-dependent reduction in NO production in RAW macrophages and exhibiting proliferative effect on INS-1 cells at 25.0 $\mu \mathrm{g} / \mathrm{ml}[42]$.

Kgopa et al. [55] evaluated the antioxidant activities of aqueous extracts of $B$. ilicifolia leaves using the 2,2azinobis (3-ethyl benzothiazolium-6-sulfonic acid (ABTS), 2,2-diphenyl-1-picrylhydrazyl (DPPH) and ferric reducing antioxidant potential (FRAP) assays. The extract exhibited activities in DPPH showing inhibition of $91.8 \%$ and the extract also showed ferric reducing abilities [55]. Sagbo et al. [52] evaluated the antioxidant activities of ethanol extracts of $B$. elliptica leaves using the ABTS, DPPH, nitric oxide (NO), hydrogen peroxide $\left(\mathrm{H}_{2} \mathrm{O} 2\right)$ and ferric reducing power assays with butylatedhydroxytoluene $(\mathrm{BHT})$ and vitamin $C$ as positive controls. The extract exhibited activities with half maximal inhibitory concentration $\left(\mathrm{IC}_{50}\right)$ values ranging from $0.5 \mathrm{mg} / \mathrm{mL}$ to $0.7 \mathrm{mg} / \mathrm{mL}$ in ABTS, DPPH, $\mathrm{H} 2 \mathrm{O} 2$ and $\mathrm{NO}$, and the extract also showed ferric reducing abilities at all tested concentrations when compared with the positive controls [52]. Sagbo et al. [52] also evaluated the antioxidant activities of ethanol extracts of $B$. ilicifolia leaves using ABTS, DPPH, nitric oxide, hydrogen peroxide $(\mathrm{H} 2 \mathrm{O} 2)$ and ferric reducing power assays with butylatedhydroxytoluene (BHT) and vitamin $\mathrm{C}$ as positive controls. The extract exhibited activities with $\mathrm{IC}_{50}$ values ranging from $0.3 \mathrm{mg} / \mathrm{mL}$ to $0.7 \mathrm{mg} / \mathrm{mL}$ in ABTS, DPPH, H2O2 and $\mathrm{NO}$, and the extract also showed ferric reducing abilities at all tested concentrations when compared with the positive controls [52]. Sagbo et al. [42] evaluated the cytotoxicity activities of aqueous leaf extract of $B$. elliptica against HepG2 liver cells using the tetrazoliumbased colorimetric 3-5-dimethyl thiazol-2-yl-2, 5diphenyl tetrazolium bromide (MTT) assay. The extract demonstrated a low level of toxicity with the $\mathrm{IC}_{50}$ value of $250.0 \mu \mathrm{g} / \mathrm{ml}$ [42].

\section{CONCLUSION}

The present review summarizes the ethnomedicinal uses, phytochemistry and biological activities of $B$. elliptica and $B$. ilicifolia. Based on the presented information, these two species are closely related and deemed as potent traditional medicines for treating and managing backache, hysteria, ulcers of the mouth, diabetes, gastro-intestinal and respiratory problems. Brachylaena elliptica and $B$. ilicifolia should be subjected to detailed phytochemical, pharmacological and toxicological evaluations aimed at correlating their medicinal uses with their phytochemistry and pharmacological properties.

\section{CONFLICT OF INTEREST}

No conflict of interest is associated with this work.

\section{REFERENCES}

[1] Van Puyvelde L, et al. Isolation of flavonoids and a chalcone from Helichrysum odoratissimum and synthesis of helichrysetin. J Nat Prod 1989; 52: 629-33. https://doi.org/10.1021/np50063a025

[2] Heinrich M, et al. Ethnopharmacology of Mexican Asteraceae (Compositae). Ann Rev Pharmacol Toxicol 1998; 38: 539-65. https://doi.org/10.1146/annurev.pharmtox.38.1.539

[3] Lourens ACU, Viljoen AM, Van Heerden FR. South African Helichrysum species: A review of the traditional uses, biological activity and phytochemistry. J Ethnopharmacol 2008; 119(3): 630-52. https://doi.org/10.1016/j.jep.2008.06.011

[4] Gouveia SC, Castilho PC. Validation of a HPLC-DAD$E S I / M^{n}$ method for caffeoylquinic acids separation, quantification and identification in medicinal Helichrysum species from Macaronesia. Food Res Int 2012; 45: 362-8. https://doi.org/10.1016/j.foodres.2011.09.023

[5] Koc S, et al. The potential medicinal value of plants from Asteraceae family with antioxidant defense enzymes as biological targets. Pharm Biol 2015; 53(5): 746-51. https://doi.org/10.3109/13880209.2014.942788

[6] Van Vuuren SF, et al. The antimicrobial and toxicity profiles of helihumulone, leaf essential oil and extracts of Helichrysum cymosum (L.) D. Don subsp. cymosum. S Afr J Bot 2006; 72: 287-90. https://doi.org/10.1016/i.sajb.2005.07.007

[7] Viegas DA, et al. Helichrysum italicum: from traditional use to scientific data. J Ethnopharmacol 2014; 151: 54-65. https://doi.org/10.1016/j.jep.2013.11.005

[8] Bessada SMF, Barreira JCM, Oliveira MBPP. Asteraceae species with most prominent bioactivity and their potential applications: a review. Indust Crops Prod 2015; 76: 604-15. https://doi.org/10.1016/j.indcrop.2015.07.073

[9] Les $\mathrm{F}$, et al. Everlasting flower (Helichrysum stoechas Moench) as a potential source of bioactive molecules with antiproliferative, antioxidant, antidiabetic and neuroprotective properties. Indust Crops Prod 2017; 108: 295-302. https://doi.org/10.1016/j.indcrop.2017.06.043

[10] Hutchings A, et al. Zulu medicinal plants: An inventory. Pietermaritzburg: University of Natal Press; 1996.

[11] Gerstner J. A preliminary checklist of Zulu names of plants with short notes. Bantu Stud 1941; 15: 277-301. https://doi.org/10.1080/02561751.1941.9676141

[12] Watt JM, Breyer-Brandwijk MG. The medicinal and poisonous plants of southern and eastern Africa. London: $E$ and S Livingstone; 1962.

[13] Varga CA, Veale DJH. Isihlambezo: utilization patterns and potential health effects of pregnancy-related traditional herbal medicine. Social Sci Med 1997; 44(7): 911-924. https://doi.org/10.1016/S0277-9536(96)00104-9 
[14] McGaw LJ, et al. Is the use of Gunnera perpensa extracts in endometritis related to antibacterial activity. Onderstepoort J Vet Res 2005; 72(2): 129-134. https://doi.org/10.4102/ojvr.v72i2.208

[15] Maroyi A. From traditional usage to pharmacological evidence: Systematic review of Gunnera perpensa L. Evidence-Based Compl Alt Med 2016; article ID 1720123. https://doi.org/10.1155/2016/1720123

[16] Dold AP, Cocks ML. The trade in medicinal plants in the Eastern Cape Province, South Africa. S Afr J Sci 2002; 98: 589-97.

[17] Cocks ML, Dold AP. Cultural significance of biodiversity: The role of medicinal plants in urban african cultural practices in the Eastern Cape, South Africa. J Ethnobiol 2006; 26(1): 6081. https://doi.org/10.2993/02780771(2006)26[60:CSOBTR]2.0.CO;2

[18] Ah Goo DFS. The contribution of the trade in medicinal plants to urban livelihoods: A case study of the informal markets in Nelson Mandela Bay Municipality, Eastern Cape. MSc Dissertation. Port Elizabeth: Nelson Mandela University; 2012.

[19] Germishuizen G, Meyer NL. Plants of southern Africa: An annotated checklist. Pretoria: Strelitzia 14, National Botanical Institute; 2003.

[20] Manning J, Goldblatt P. Plants of the Greater Cape Floristic region, Vol 1: The core Cape Flora. Pretoria: Strelitzia 29, South Africa National Biodiversity Institute; 2012.

[21] Van Wyk B, Van Wyk P. Field guide to trees of southern Africa. Cape Town: Struik Nature; 2013.

[22] Schmidt E, Lotter M, McCleland W. Trees and shrubs of Mpumalanga and Kruger National Park. Johannesburg: Jacana Media; 2017.

[23] Palgrave MC. Keith Coates Palgrave trees of southern Africa. Cape Town: Struik Publishers; 2002.

[24] Gerstner J. A preliminary checklist of Zulu names of plants with short notes. Bantu Stud 1939; 13: 49-64. https://doi.org/10.1080/02561751.1939.9676090

[25] Sobiecki JF. A preliminary inventory of plants used for psychoactive purposes in southern African healing traditions. Transactions Royal Soc S Afr 2002; 57: 1-24. https://doi.org/10.1080/00359190209520523

[26] Sobiecki JF. A review of plants used in divination in southern Africa and their psychoactive effects. Southern Afr Hum 2008; 20: 333-51.

[27] Iwalewa EO, et al. Inflammation: the foundation of diseases and disorders: A review of phytomedicines of South African origin used to treat pain and inflammatory conditions. Afr J Biotechnol 2007; 6(25): 2868-85. https://doi.org/10.5897/AJB2007.000-2457

[28] McGaw LJ, Eloff JN. Ethnoveterinary use of southern African plants and scientific evaluation of their medicinal properties. $J$ Ethnopharmacol 2008; 119: 559-74.

https://doi.org/10.1016/j.jep.2008.06.013

[29] Adebayo SA, Amoo SO. South African botanical resources: A gold mine of natural pro-inflammatory enzyme inhibitors? S Afr J Bot 2019; 123: 214-27. https://doi.org/10.1016/j.sajb.2019.03.020

[30] Dold AP, Cocks ML. Traditional veterinary medicine in the Alice district of the Eastern Cape Province, South Africa. S Afr J Sci 2001; 97: 375-9.

[31] Stark TD, Mtui DJ, Balemba OB. Ethnopharmacological survey of plants used in the traditional treatment of gastrointestinal pain, inflammation and diarrhea in Africa: Future perspectives for integration into modern medicine. Animals 2013; 3 : 158-227. https://doi.org/10.3390/ani3010158

[32] Palmer E, Pitman N. Trees of southern Africa covering all known indigenous species in the Republic of South Africa,
South-West Africa, Botswana, Lesotho and Swaziland. Cape Town: AA Balkema; 1972.

[33] Beentje HJ. The genus Brachylaena (Compositae: Mutisieae). Kew Bull 2000; 55(1): 1-41. https://doi.org/10.2307/4117759

[34] Van Wyk B-E. A review of Khoi-San and Cape Dutch medical ethnobotany. J Ethnopharmacol 2008; 119: 331-41. https://doi.org/10.1016/j.jep.2008.07.021

[35] Deutschländer MS, Lall N, Van De Venter M. Plant species used in the treatment of diabetes by South African traditional healers: An inventory. Pharm Biol 2009; 47(4): 348-65. https://doi.org/10.1080/13880200902752959

[36] Deutschländer MS. Isolation and identification of a novel antidiabetic compound from Euclea undulata Thunb. PhD Thesis. Pretoria: University of Pretoria; 2010. https://doi.org/10.1016/j.sajb.2010.02.018

[37] Afolayan AJ, Sunmonu TO. In vivo studies on antidiabetic plants used in South African herbal medicine. J Clin Biochem Nutr 2010; 47: 98-106. https://doi.org/10.3164/jcbn.09-126R

[38] Velembo-Mhlauli SA. Brachylaena elliptica (Thunb.) DC. Kirstenbosch National Botanical Garden; 2016. Available from: http://pza.sanbi.org/brachylaena-elliptica, accessed on 23 February 2020.

[39] Subramoniam A. Plants with anti-diabetes mellitus properties. New York: CRC Press; 2016. https://doi.org/10.1201/9781315371481

[40] Adam SAE. Isolation and identification of antidiabetic compounds from Brachylaena discolor DC. MSc Dissertation. Pietermaritzburg: University of KwaZulu-Natal; 2017.

[41] Odeyemi S, Bradley G. Medicinal plants used for the traditional management of diabetes in the Eastern Cape, South Africa: Pharmacology and toxicology. Molecules 2018; 23: 2759 . https://doi.org/10.3390/molecules23112759

[42] Sagbo IJ, et al. In vitro antidiabetic activity and mechanism of action of Brachylaena elliptica (Thunb.) DC. Evidence-Based Compl Alt Med 2018; article ID 4170372.

https://doi.org/10.1155/2018/4170372

[43] Ondo ZG. How traditional healers diagnose and treat diabetes mellitus in the Pretoria Mamelodi area and how do these purported medications comply with complementary and alternative medicine regulations. MSc Dissertation. Pretoria: University of Pretoria; 2019. https://doi.org/10.1254/jpssuppl.WCP2018.0 PO4-8-5

[44] Hutchings A. A survey and analysis of traditional medicinal plants as used by the Zulu, Xhosa and Sotho. Bothalia 1989; 19: 111-23. https://doi.org/10.4102/abc.v19i1.947

[45] Akhalwaya $S$. The antimicrobial investigation of indigenous South African medicinal plants against oral pathogens. MSc Dissertation. Johannesburg: University of the Witwatersrand; 2017.

[46] Pooley E. The complete field guide to trees of Natal, Zululand and Transkei. Durban: Natal Flora Publications Trust; 1993.

[47] Long C. Swaziland's flora: Siswati names and uses. Mbambane, Swaziland: Swaziland National Trust Commission, 2005. Available from: http://www.sntc.org.sz/ index.asp, accessed on 14 January 2020.

[48] Olajuyigbe OO, Afolayan AJ. Ethnobotanical survey of medicinal plants used in the treatment of gastrointestinal disorders in the Eastern Cape Province, South Africa. J Med PI Res 2012; 6(18): 3415-24. https://doi.org/10.5897/JMPR11.1707

[49] Cocks ML, Wiersum KF. The significance of plant diversity to rural households in Eastern Cape province of South Africa. Forests, Trees Livelih 2003; 13(1): 39-58. https://doi.org/10.1080/14728028.2003.9752443 
[50] Zdero C, Bohlmann F. Sesquiterpene lactones from the genus Brachylaena. Phytochem 1987; 26: 2597-601. https://doi.org/10.1016/S0031-9422(00)83886-8

[51] Sagbo IJ. Phytochemical analysis and antibacterial properties of aqueous and ethanolic extracts of Brachylaena elliptica and Brachylaena ilicifolia. MSc Dissertation. Alice: University of Fort Hare; 2015.

[52] Sagbo IJ, Afolayan AJ, Bradley G. Antioxidant, antibacterial and phytochemical properties of two medicinal plants against the wound infecting bacteria. Asian Pac J Trop Biomed 2017; 7(9): 817-825.

https://doi.org/10.1016/j.apjtb.2017.08.009

[53] Marles RJ, Farnsworth NR. Antidiabetic plants and their active constituents. Phytomed 1995; 2: 133-89. https://doi.org/10.1016/S0944-7113(11)80059-0

[54] Kgopa AH, et al. Antioxidant activity of selected plants of the Great Fish River Reserve, Eastern Cape, South Africa. Afr J Range Forage Sci 2010; 27(2): 109-12. https://doi.org/10.2989/10220119.2010.503581

Received on 26-07-2020

Accepted on 21-09-2020

Published on $15-10-2020$

DOI: https://doi.org/10.29169/1927-5951.2020.10.05.7

(C) 2020 Alfred Maroyi; Licensee SET Publisher.

This is an open access article licensed under the terms of the Creative Commons Attribution Non-Commercial License (http://creativecommons.org/licenses/by-nc/3.0/) which permits unrestricted, non-commercial use, distribution and reproduction in any medium, provided the work is properly cited. 